BMJ. Vol 6 No 2, 2019: 216-220

ISSN : 2615-7047

DOI: https://doi.org/10.36376/bmj.v6i2

Disubmit 3 September 2019

Diterima 30 Desember 2019

\title{
GAMBARAN KEBIASAAN SARAPAN PADA ANAK SEKOLAH DASAR DI KABUPATEN BADUNG
}

\section{DESCRIPTION OF BREAKFAST HABITS IN ELEMENTARY SCHOOL CHILDREN IN BADUNG REGENCY}

\author{
${ }^{1}$ Komang Ayu Resiyanthi, ${ }^{2}$ Ni Wayan Suniyadewi \\ ${ }_{1,2}$ Stikes Wira Medika Bali
}

\begin{abstract}
ABSTRAK
Sarapan merupakan hal penting juga untuk memenuhi gizi bagi setiap orang untuk mengawali aktivitasnya. Sarapan adalah kegiatan makan dan minum yang dilakukan antara bangun pagi sampai jam 9 untuk memenuhi sebagian yaitu 15-30\% kebutuhan gizi harian (Hardinsyah, 2012). Tujuan dari penelitian ini untuk mengetahui gambaran kebiasaan sarapan pada siswa sekolah dasar di Kabupaten Badung. Jenis penelitian ini adalah deskriptif, yakni menggambarkan kebiasaan sarapan pada siswa sekolah dasar di Kabupaten Badung. Lokasi penelitian ini akan dilaksanakan pada empat sekolah dasar di Kabupaten badung yaitu SD 1 Kuta, SD 3 Kuta, SD 2 Kuta dan SD 1 Jagapati menggunakan 154 Siswa SD yang diambil dengan purposive sampling. Dari 154 siswa yang diteliti didapatkan bahwa sebagian besar siswa Sekolah Dasar di Kabupaten Badung terbiasa sarapan yaitu sebanyak 120 orang $(77,9 \%)$, sebagian besar sarapan setiap pagi hari yaitu sebanyak 109 orang (70,8\%), sebagian besar sarapan pada jam 6-7 pagi yaitu sebanyak 149 orang $(96,8 \%)$, sebagian besar sarapan di rumah yaitu sebanyak 152 orang $(98,7 \%)$ dan sebagian besar dengan menu yang berganti-ganti yaitu sebanyak 121 orang $(78,6 \%)$. Disarankan petugas kesehatan memberikan penyuluhan kesehatan tentang pentingnya sarapan yang sehat baik pada siswa dan kepada orangtua karena selain untuk kesehatan juga sangat bermanfaat untuk meningkatkan konsentrasi dan prestasi siswa.
\end{abstract}

Kata Kunci: Kebiasaan, Sarapan, Anak sekolah dasar.

\section{ABSTRACT}

Breakfast is important for fulfilling nutrition for everyone to start their activities. Breakfast is an eating and drinking activity that is carried out between getting up in the morning until 9 o'clock to fulfill a 15-30\% of daily nutritional needs (Hardinsyah, 2012). The purpose of this study was to determine the description of breakfast habits in elementary school students in Badung Regency. This type of research is descriptive, which describes the breakfast habits of elementary school students in Badung Regency. The location of this research will be carried out in four elementary schools in Badung Regency, namely SD 1 Kuta, SD 3 Kuta, SD 2 Kuta and SD 1 Jagapati using 154 elementary students taken by purposive sampling. Of the 154 students studied it was found that the majority of elementary school students in Badung Regency are used to have breakfast as many as 120 people (77.9\%). Most of the breakfast time is every morning 109 people (70.8\%), most of

Balimedikajurnal.com 
BMJ. Vol 6 No 2, 2019: 216-220

DOI: https://doi.org/10.36376/bmj.v6i2

the breakfast hours is at 6-7 in the morning as many as 149 people (96.8\%), the majority of breakfast at home is as many as 152 people (98.7\%) and most of the menus are alternating as many as 121 people (78.6\%). It is recommended that health workers provide health education on the importance of a healthy breakfast both for students and parents because in addition to health, it is also very beneficial to improve student concentration and achievement.

Keywords: Habits, Breakfast, Elementary school children.

\begin{tabular}{ll}
\hline Alamat Korespondensi & $\begin{array}{l}\text { STIKes Wira Medika Bali Jln. Kecak No. 9A Gatot Subroto Timur } \\
\text { Denpasar } \\
\text { Email }\end{array}$ \\
\hline
\end{tabular}

\section{PENDAHULUAN}

Salah satu indikator kualitas sumber daya manusia adalah keadaan gizi yang baik, dimana kebutuhan dasar dapat tercukupi baik dari segi kualitas maupun kuantitasnya (Sungkowo, 2010). Sarapan merupakan hal penting juga untuk memenuhi gizi bagi setiap orang untuk mengawali aktivitasnya. Sarapan adalah kegiatan makan dan minum yang dilakukan antara bangun pagi sampai jam 9 untuk memenuhi sebagian yaitu 15-30\% kebutuhan gizi harian (Hardinsyah, 2012). Sarapan bertujuan untuk memenuhi kebutuhan zat gizi di pagi hari, sebagai bagian dari pemenuhan gizi seimbang serta bermanfaat untuk mencegah berbagai penyakit. Kebiasaan makan pagi termasuk dalam 13 pesan dasar gizi yang seimbang. Bagi anak sekolah makan pagi dapat meningkatkan konsentrasi belajar dan memudahkan dalam berkonsentrasi menyerap pelajaran sehingga dapat meningkatkan prestasi belajar (Depkes, 2010). Kebiasaan sarapan adalah tingkah laku manusia atau kelompok manusia dalam memenuhi kebutuhannya akan sarapan yang meliputi sikap, kepercayaan dan pemilihan makanan. Bagi sebagian orang sarapan merupakan kegiatan yang tidak menggairahkan karena nafsu makan belum ada. Selain itu, keterbatasan menu yang tersaji di meja makan dan waktu yang terbatas menyebabkan orang sering meninggalkan sarapan (Khomsan, 2010).

Berdasarkan penelitian yang dilakukan oleh Maidarmi K, dkk tahun (2014) menunjukkan bahwa siswa yang memiliki konsentrasi tinggi lebih banyak pada siswa dengan asupan energi sangat baik $(60,7 \%)$ dibandingkan dengan asupan energi kurang $(44,3 \%)$ dan sangat kurang $(51,9 \%)$. Terdapat hubungan yang bermakna antara asupan energi sarapan terhadap tingkat konsentrasi anak. Tujuan dari penelitian ini untuk mengetahui gambaran kebiasaan sarapan pada siswa sekolah dasar di Kabupaten Badung Tahun 2016.

\section{METODE PENELITIAN}

Jenis penelitian ini adalah deskriptif, yakni menggambarkan kebiasaan sarapan pada siswa sekolah dasar di Kabupaten Badung. Lokasi penelitian ini akan dilaksanakan pada empat sekolah dasar di Kabupaten badung yaitu SD 1 Kuta, SD 3 Kuta, SD 2 Kuta dan SD 1 Jagapati. Penelitian ini akan dilaksanakan pada bulan Desember 2016. sampel yang digunakan dalam penelitian ini adalah sebanyak 154 
DOI: https://doi.org/10.36376/bmj.v6i2

orang siswa sekolah dasar yang diambil dengan teknik purposive sampling. Kriteria Inklusi dalam penelitian ini adalah siswa sekolah dasar yang tidak sedang sakit dan masuk kesekolah pada saat penelitian berlangsung dan kriteria ekslusinya adalah siswa yang menolak menjadi responden. Variabel dalam penelitian ini adalah kebiasaan sarapan. Dalam penelitian ini peneliti mengajak 2 enumerator dari mahasiswa yang bertugas untuk membantu saat penyebaran kuesioner kebiasaan sarapan kepada sampel. Instrumen dalam penelitian ini adalah kuesioner yang berisi 5 pertanyaan pilihan tentang kebiasaan sarapan. Metode analisis yang digunakan dalam penelitian ini adalah Analisis Deskriptif Persentase.

\section{Karakteristik Responden}

\section{HASIL DAN DISKUSI}

Karakteristik responden yaitu siswa-siswi sekolah dasar yang diidentifikasi berdasarkan umur, jenis kelamin, tinggi badan dan berat badan. Hasil analisis masing-masing variabel ditunjukkan dalam tabel berikut

Tabel 1

Distribusi responden menurut Umur pada Siswa Sekolah Dasar di Kabupaten Badung

\begin{tabular}{rccc}
\hline & Variabel & $\mathbf{f}(\mathbf{n}=\mathbf{1 5 4})$ & $\mathbf{\%}$ \\
\hline & Umur & Frekuensi & Persentase \\
\hline$\bullet$ & 8 tahun & 4 & 2,6 \\
\hline$\bullet$ & 9 tahun & 48 & 31,2 \\
\hline$\bullet$ & 11 tahun & 81 & 52,6 \\
\hline Total & & 21 & 13,6 \\
\hline
\end{tabular}

Berdasarkan Tabel 1, menunjukkan bahwa sebagian besar siswa Sekolah

Dasar di Kabupaten Badung berumur 10 tahun yaitu sebanyak 81 orang $(52,6 \%)$.

Tabel 2

Distribusi responden menurut Jenis Kelamin pada Siswa Sekolah Dasar di Kabupaten Badung

\begin{tabular}{rccc}
\hline \multicolumn{1}{c}{ Variabel } & $\mathbf{f}(\mathbf{n}=\mathbf{1 5 4})$ & $\%$ \\
\hline Jenis Kelamin & Frekuensi & Persentase \\
\hline$\bullet$ & Laki-Laki & 74 & 48,1 \\
\hline$\bullet$ & Perempuan & 80 & 51,9 \\
\hline Total & $\mathbf{1 5 4}$ & $\mathbf{1 0 0 , 0}$ \\
\hline
\end{tabular}

Berdasarkan Tabel 2, menunjukkan bahwa sebagian besar siswa Sekolah Dasar di Kabupaten Badung berjenis kelamin perempuan yaitu sebanyak 80 orang $(51,9 \%)$. 
BMJ. Vol 6 No 2, 2019: 216-220

ISSN : 2615-7047

DOI: https://doi.org/10.36376/bmj.v6i2

Gambaran kebiasaan sarapan

Gambaran kebiasaan sarapan pada siswa-siswi sekolah dasar di Kabupaten Badung tergambar pada tabel dibawah ini:

Tabel 3

Distribusi responden menurut kebiasaan sarapan pada Siswa

Sekolah Dasar

di Kabupaten Badung

Bulan Januari - Februari 2017

\begin{tabular}{|c|c|c|}
\hline Variabel & $f(n=154)$ & $\%$ \\
\hline Kebiasaan sarapan & Frekuensi & Persentase \\
\hline - $\mathrm{Ya}$ & 120 & 77,9 \\
\hline - Tidak & 34 & 22,1 \\
\hline \multicolumn{3}{|l|}{ Waktu sarapan } \\
\hline - $\quad$ Setiap pagi & 109 & 70,8 \\
\hline $\begin{array}{ll}\text { - } & \text { Setiap pergi } \\
& \text { sekolah } \\
\end{array}$ & 42 & 27,3 \\
\hline - Kalau lapar & 3 & 1,9 \\
\hline \multicolumn{3}{|l|}{ Jam sarapan } \\
\hline - Jam 6-7 pagi & 149 & 96,8 \\
\hline $\begin{array}{ll}\text { - } & \text { Saat istirahat } \\
\text { sekolah }\end{array}$ & 1 & 0,6 \\
\hline $\begin{array}{l}\text { - } \begin{array}{l}\text { Setelah pulang } \\
\text { sekolah }\end{array} \\
\end{array}$ & 4 & 2,6 \\
\hline \multicolumn{3}{|l|}{ Tempat sarapan } \\
\hline - Rumah & 152 & 98,7 \\
\hline - Perjalanan sekolah & 2 & 1,3 \\
\hline - Sekolah & 0 & 0 \\
\hline \multicolumn{3}{|l|}{ Menu sarapan } \\
\hline - Berganti-ganti & 121 & 78,6 \\
\hline - Kadang-kadang & 30 & 19,5 \\
\hline - $\quad$ Tidak berganti & 3 & 1,9 \\
\hline Total & 154 & 100,0 \\
\hline
\end{tabular}

Berdasarkan Tabel 3, menunjukkan bahwa sebagian besar siswa Sekolah Dasar di Kabupaten Badung terbiasa sarapan yaitu sebanyak 120 orang $(77,9 \%)$, sebagian besar sarapan setiap pagi hari yaitu sebanyak 109 orang $(70,8 \%)$, sebagian besar sarapan pada jam 6-7 pagi yaitu sebanyak 149 orang $(96,8 \%)$, sebagian besar sarapan di rumah yaitu sebanyak 152 orang $(98,7 \%)$ dan sebagian besar dengan menu yang berganti-ganti yaitu sebanyak 121 orang $(78,6 \%)$.

Menurut penelitian Sukiniarti (2015), kebiasaan makan pagi sebelum berangkat sekolah dari hasil penelitian adalah sebagai $89,66 \%$ anak setiap pagi selalu makan pagi sebelum berangkat sekolah, 5,17\% setiap pagi anak hanya cukup makan kue-kue saja, selebihnya diberi uang untuk jajan dan $5,17 \%$ anak tidak sempat makan pagi, sehingga setiap hari diberi uang sangu untuk jajan yang disukai anak. Penelitian Hardinsyah dan Aries (2012) 
BMJ. Vol 6 No 2, 2019: 216-220

ISSN : $2615-7047$

DOI: https://doi.org/10.36376/bmj.v6i2

menyatakan sarapan yang baik dilakukan maksimal pukul 09.00 WIB. Sebagian besar sampel yang sarapan sebelum pukul 07.00 pagi melakukan sarapan di rumah (65.0\%). Waktu dan lokasi sarapan subjek dalam penelitian ini tergolong baik.

\section{Simpulan}

\section{SIMPULAN DAN SARAN}

Dari 154 siswa yang diteliti didapatkan bahwa sebagian besar siswa Sekolah Dasar di Kabupaten Badung terbiasa sarapan yaitu sebanyak 120 orang (77,9\%), sebagian besar sarapan setiap pagi hari yaitu sebanyak 109 orang $(70,8 \%)$, sebagian besar sarapan pada jam 6-7 pagi yaitu sebanyak 149 orang $(96,8 \%)$, sebagian besar sarapan di rumah yaitu sebanyak 152 orang $(98,7 \%)$ dan sebagian besar dengan menu yang berganti-ganti yaitu sebanyak 121 orang $(78,6 \%)$.

\section{Saran}

Memberikan penyuluhan kesehatan tentang pentingnya sarapan yang sehat baik pada siswa dan kepada orangtua karena selain untuk kesehatan juga sangat bermanfaat untuk meningkatkan konsentrasi dan prestasi siswa.

\section{DAFTAR PUSTAKA}

Hardinsyah, Arni. 2012. Hubungan Status Gizi dengan Prestasi Belajar Siswa Di Sekolah Dasar Negeri 2 Selo Kecamatan Selo Kabupaten Boyolali. Karya Tulis Ilmiah. Universitas Muhammadiyah Surakarta.

Sukiniarti Jurnal Pendidikan Biologi Indonesia Volume 1 Nomor 32015 (Issn: 2442-3750) (Halaman 315-321), Kebiasaan Makan Pagi Kebiasaan Makan Pagi Pada Anak Usia SD dan Hubungannya Dengan Tingkat Kesehatan Dan Prestasi Belajar Sukiniarti 1.

Depkes RI. 2010. Pedoman Umum Gizi Seimbang. Jakarta: Direktorat Jenderal Bina Kesehatan Masyarakat

Khomsan A. Pangan Dan Gizi Untuk Kesehatan. Jakarta: Pt.Raja Gravindo Persada; 2003

Sungkowo. 2010. Kebutuhan Pokok dan SDM Berkualitas. (Available). web: http://sinarharapan.co.id/berita/0302/22opio01.html (5 Maret 2016).

Hardinsyah. 2012. Keynote Speech For Healthy Breakfast Symposium. Pergizi Pangan Indone-sia. Http://Pergizi.Org Diakses Pada Tanggal 10 Mei 2017.

Sukiniarti Jurnal Pendidikan Biologi Indonesia Volume 1 Nomor 32015 (Issn: 2442-3750) (Halaman 315-321), Kebiasaan Makan Pagi Kebiasaan Makan Pagi Pada Anak Usia SD dan Hubungannya Dengan Tingkat Kesehatan Dan Prestasi Belajar Sukiniarti 1. 